\title{
Exigência de Metionina mais Cistina para Codornas Japonesas em Crescimento ${ }^{1}$ \\ Rogério Pinto ${ }^{2}$, Aloízio Soares Ferreira ${ }^{3}$, Juarez Lopes Donzele ${ }^{3}$, Luiz Fernando Teixeira Albino $^{3}$, Martinho de Almeida e Silva ${ }^{4}$, Rita da Trindade Ribeiro Nobre Soares ${ }^{5}$, Ciane Aparecida Pereira ${ }^{6}$
}

\begin{abstract}
RESUMO - Foram utilizadas 540 codornas fêmeas, com idade inicial de sete dias e peso médio de 21,50 g, durante 35 dias. O delineamento foi em blocos ao acaso, com cinco repetições e 18 aves por unidade experimental. Os tratamentos consistiram de seis relações metionina mais cistina digestível: lisina digestível $(0,48,0,53,0,58,0,63,0,68$ e 0,75$)$. Foram estudadas as variáveis peso final (g), ganho de peso $(\mathrm{g})$, consumo alimentar (g), conversão alimentar (g/g), empenamento (\%), composição química corporal (matéria seca, água, proteína e extrato etéreo) e deposição de proteína e gordura corporais. Os tratamentos influenciaram de forma quadrática o consumo alimentar, a conversão alimentar, o empenamento, a composição química (matéria seca, água, proteína e extrato etéreo) e a deposição de proteína corporal, e linearmente o peso final e o ganho de peso das codornas. A melhor relação metionina mais cistina digestível: lisina digestível para as codornas japonesas em crescimento foi de 0,66 , sendo a exigência em metionina mais cistina digestível estimada em $0,758 \%$, para consumo de $91,43 \mathrm{mg}$ de metionina mais cistina digestível.
\end{abstract}

Palavras-chave: aminoácidos sulfurosos, codornas japonesas de postura, Coturnix coturnix japonica, digestibilidade, proteína ideal

\section{Methionine plus Cystine Requirement for Growing Japanese Quails}

\begin{abstract}
Five hundred and forty 7-days old female quails, averaging $21.50 \mathrm{~g}$, were used during 35 days. A completely randomized blocks design with five replicates and 18 females per experimental unity was used to study the effect of six digestible methionine plus cystine: digestible lysine ratios $(0.48,0.53,0.58,0.63,0.68$ and 0.75$)$ on the traits evaluated during the growing period. Final weight $(\mathrm{g})$, weight gain $(\mathrm{g})$, feed intake $(\mathrm{g})$, feed conversion $(\mathrm{g} / \mathrm{g})$, feather rate $(\%)$, chemical composition $(\%)$ (dry matter, water, crude protein and ether extract) and body protein and fat deposition $(\mathrm{g})$. The effect of the amino acids on feed intake (g), feed conversion $(\mathrm{g} / \mathrm{g})$, feather rate $(\%)$, chemical composition (\%) (dry matter, water, crud protein and ether extract) and protein deposition was quadratic and the effect on final body weight $(\mathrm{g})$ and weight gain $(\mathrm{g})$ was linear. The best estimated digestible methionine plus cystine: digestible lysine ratio was .66 and the estimated digestible methionine plus cystine requirement for growing Japanese quail was .758\%, for a intake of $91.43 \mathrm{mg}$ of digestible methionine plus cystine intake.
\end{abstract}

Key Words: Coturnix coturnix japonica, digestibility, ideal protein, laying Japanese quails, sulfur amino acid

\section{Introdução}

As condições nutricionais estabelecidas durante o período de crescimento podem influenciar o desempenho das aves na fase de produção, porém, a maioria dos estudos com codornas têm sido conduzidos com o objetivo de determinar as exigências nutricionais das aves de postura na fase de produção, sendo escassos os trabalhos direcionados para determinar as exigências na fase de crescimento. Aliado a isto, o fato de as codornas possuírem amadurecimento precoce (35 a 42 dias de idade) pode induzir a necessidade de programas alimentares que maximizem a taxa de crescimento, aliando-se desenvolvimento corporal à maturidade sexual, permitindo assim uma uniformidade do plantel e garantindo-se normalidade na fase de produção.

As rações das aves, formuladas à base de milho e farelo de soja, são deficientes entre outros aminoácidos, em metionina, aminoácido essencial para o desenvolvimento e desempenho normal das aves, devendo ser suplementado com aminoácidos sintéticos. Entretanto, outros fatores como estresse, linhagem, ambientes térmicos, teor de proteína na ração, energia digestível e principalmente os alimentos utilizados na formulação, podem influenciar as

\footnotetext{
${ }_{1}^{1}$ Parte da tese de Doutorado do primeiro autor.

2 Doutor em Zootecnia pelo Programa de Pós-graduação da UFV, Rua dos Estudantes, no 25 , centro, Viçosa - MG. CEP: 3657.000. E.mail: rpinto@funec.br

3 Professores - Departamento de Zootecnia, UFV - CEP: 36570.000, Viçosa - MG.

4 Professor da Universidade Federal de Minas Gerais.

5 Professora da Universidade Estadual do Norte Fluminense.

${ }^{6}$ Zootecnista, Estudante de mestrado, CCA, DZO - Universidade Federal de Viçosa.
} 
exigências deste aminoácido pelas aves (Conhalato, 1998).

A metionina e a cistina são consideradas aminoácidos fisiologicamente essenciais para mantença, crescimento dos animais e para o desenvolvimento das penas.

A metionina, em condições normais, pode ser catabolizada e convertida em cistina. Entretanto, esta conversão não é reversível, pois a cistina não pode ir a metionina e por isso torna-se necessário determinar os níveis adequados destes aminoácidos, a fim de se atender esta inter-relação (Barbosa, 1998).

Tem-se também considerado que, no mínimo, 55\% dos aminoácidos sulfurosos na ração devem ser fornecidos na forma de metionina para as aves em todas as fases de criação (Rostagno et al., 1996).

A falta de informações sobre o nível aminoacídico para codornas japonesas em crescimento norteou a necessidade desta pesquisa, que foi conduzida objetivando-se estabelecer a relação metionina mais cistina digestível: lisina digestível e estimar a exigência em metionina mais cistina e digestível para codornas japonesas em crescimento.

\section{Material e Métodos}

O experimento foi realizado numa sala experimental da seção de Avicultura do Departamento de Zootecnia do Centro de Ciências Agrárias da Universidade Federal de Viçosa, no período de janeiro a fevereiro 2001.

Foram utilizadas 540 codornas fêmeas (Coturnix coturnix japonica), com idade inicial de sete dias e peso médio de 21,50 g, durante 35 dias.

O delineamento experimental foi em blocos ao acaso para evitar o efeito do posicionamento das gaiolas nos andares e nas baterias sobre os tratamentos. Os tratamentos eram constituídos de seis relações metionina mais cistina digestível: lisina digestível $(0,48,0,53,0,58,0,63,0,68$ e 0,75$)$ e cinco repetições, com 18 animais por unidade experimental.

As aves foram alojadas em duas baterias, dispostas em seis andares de quatro gaiolas por andar. As gaiolas possuíam $0,60 \mathrm{~m}$ de comprimento, $0,30 \mathrm{~m}$ de profundidade e $0,25 \mathrm{~m}$ de altura, tendo comedouro na frente e bebedouro na lateral da gaiola, ambos do tipo calha.

Sob o piso das gaiolas foi colocada bandeja de chapa metálica galvanizada para coleta de fezes.

Os animais foram submetidos à ração basal, deficiente em metionina mais cistina, formulada à base de milho e farelo de soja, contendo $20,24 \%$ de proteína bruta (PB), $2.900 \mathrm{kcal}$ de EM/kg de ração, $1,15 \%$ de lisina digestível e $0,555 \%$ de metionina mais cistina digestível, correspondendo a uma relação de metionina mais cistina: lisina de 0,48 .

A composição percentual e calculada da ração basal encontra-se na Tabela 1.

Esta ração basal foi suplementada com cinco níveis de DL-metionina (99\%), em substituição ao amido de milho, correspondendo aos níveis de 0,555 (conteúdo da dieta basal, sem suplementação), 0,610, $0,667,0,725,0,782$ e $0,863 \%$ de metionina mais cistina digestível, permanecendo as rações isocalóricas.

As rações foram formuladas com base no conteúdo aminoacídico digestível verdadeiro dos alimentos, determinados pelo método de alimentação precisa de Sibbald, utilizando galos cecectomizados, apresentado em Rostagno et al. (2000), e as exigências nutricionais das codornas japonesas em crescimento, constantes no NRC (1994), exceto para proteína bruta (PB), metionina e metionina mais cistina. Para todos os outros aminoácidos, foram mantidas as relações aminoacídicas com a lisina, de acordo com o proposto pelo NRC (1994), por meio da suplementação de aminoácidos sintéticos em substituição ao amido de milho, em todas as rações.

O fornecimento de água e ração para as codornas foi à vontade por todo o período experimental.

O programa de iluminação foi único para todos os grupos experimentais, sendo fornecido luz artificial por 24 horas até o término do período experimental.

As mensurações de temperatura e umidade dentro da sala experimental foram registradas por meio de termômetros de máxima e mínima e de bulbo seco e bulbo úmido.

Foram avaliados o peso final $(\mathrm{g})$, ganho de peso (g), consumo de ração $(\mathrm{g})$, conversão alimentar $(\mathrm{g} / \mathrm{g})$, empenamento (\%), composição química da caraça (\%) (matéria seca, água, proteína, extrato etéreo) e deposição de proteína corporal $(\mathrm{g})$.

Para determinação do empenamento, foram sacrificadas por asfixia duas codornas em cada unidade experimental, selecionadas pelo peso médio da unidade experimental, depenadas "a seco" e as penas posteriormente pesadas para cálculo do empenamento.

Para o estudo da composição química corporal foram abatidas, ao término do período experimental, cinco codornas por unidade experimental, selecionadas pelo peso médio dentro de cada uni- 
Tabela 1 - Composição percentual e calculada da ração basal

Table 1 - Percentual and calculated Composition of basal diet

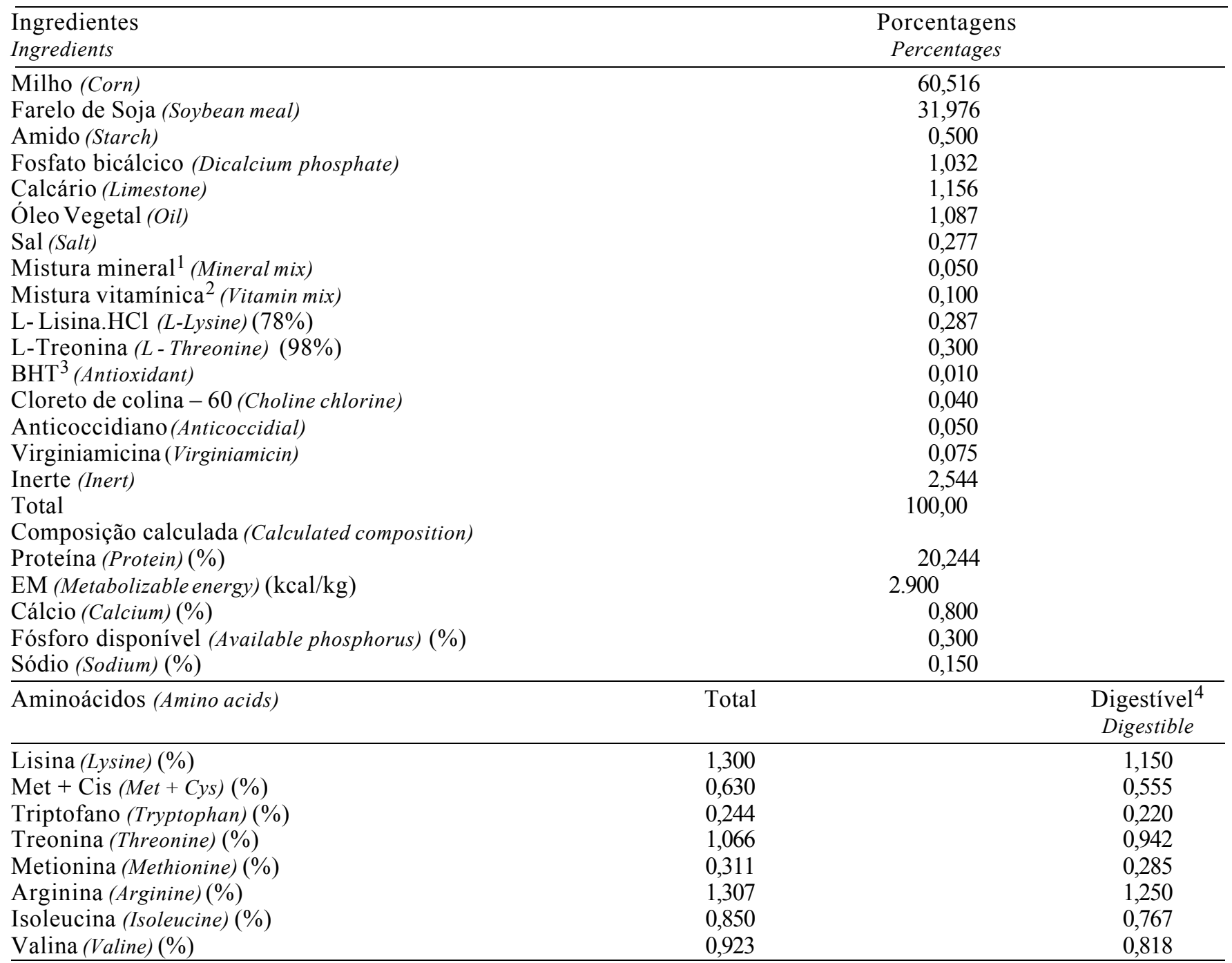

${ }^{1}$ Conteúdo/kg de mistura vitamínica (Content/kg of vitamin mix): Vit. A - 12.000 .000 U.I.; Vit. D3 - 3.600.000 U.I.; Vit. B -2.500 mg; Vit $\mathrm{B}_{2}-8.000 \mathrm{mg}$; Vit. $\mathrm{B}_{6}-5.000 \mathrm{mg}$; Ác. pantotênico (pantothenic acid) $-12.000 \mathrm{mg}$; Biotina (biotin) - $200 \mathrm{mg}$; Vit. $\mathrm{K}_{3}-3.000 \mathrm{mg}$; Ác. fólico (folic acid) - $1.500 \mathrm{mg}$; Ác.nicotínico (nicotinic acid) - $40.000 \mathrm{mg}$; Vit. B $12-20.000 \mathrm{mcg}$; Selênio (seleniun) - $150 \mathrm{mg}$; Veículo, q.s.p. - $1000 \mathrm{~g}$.

${ }^{2}$ Conteúdo/kg de mistura mineral (Content/kg of mineral mix): Manganês (manganese) - 160,0 g; Ferro (iron) - 100,0 g; Cobre (copper) - 20,0 g; Zinco (zinc) - 100,0 g; Cobalto (cobalt) - 2,0 g; lodo (iodine) - 2,0 g; Veículo (vehicle)q.s.p. - $1000 \mathrm{~g}$.

${ }^{3}$ Antioxidante(Antioxidant).

${ }^{4}$ Conteúdo aminoacídico digestível verdadeiro, obtido por meio do método de alimentação precisa de Sibbald, utilizando galos cecectomizados, constantes em Rostagno et al. (2000) (True digestible amino acid content, obtained by means of feeding method of Sibbald, using cecectomized roosters, constant in Rostagno et al. [2000]).

dade experimental, após um período de jejum de dez horas, sendo sangradas, depenadas, resfriadas, congeladas e moídas inteiras (sem evisceração), para determinação dos teores de matéria seca, extrato etéreo e proteína bruta, segundo descrito em Silva (1990).

A deposição de proteína corporal foi calculada por meio do abate feito a parte de um grupo adicional de 20 codornas aos sete dias de idade, comparadas com aquelas codornas abatidas ao término do experimento. Para o cálculo final da deposição de proteína corporal, corrigiu-se o valor encontrado na amostra, para o peso médio do animal vivo em cada unidade experimental.

Os dados foram submetidos às análises estatísticas, utilizando-se o programa Sistema Para Análises Estatísticas e Genética (SAEG), Universidade Federal de Viçosa (1997). 


\section{Resultados e Discussão}

As mensurações das temperaturas máxima e mínima médias e a umidade relativa dentro da sala experimental, estão apresentadas na Tabela 2.

As codornas, por possuírem grande área corporal em relação ao peso, na fase de crescimento, são dependentes de ambiente termo-higrométrico ideal $\left(1^{\mathrm{a}}\right.$ semana de idade, $38 \mathrm{C}^{\mathrm{o}}$ e $65 \%$ de UR; $2^{\mathrm{a}}$ semana de idade $32 \mathrm{C}^{0}$ e 60 de UR; $3^{\mathrm{a}}$ semana de idade $27 \mathrm{C}^{\mathrm{o}}$ e $60 \%$ de UR; a partir da $4^{\mathrm{a}}$ semana de idade 21 a $25 \mathrm{C}^{0}$ e $60 \%$ de UR), segundo Reis (1980) e Singh \& Narayam (2002). Dessa forma, até a terceira semana de idade, a sala experimental foi aquecida com a utilização de lâmpadas de infravermelho, mantendo o ambiente adequado para o melhor desempenho das codornas. A partir da quarta semana de idade, o aquecimento foi retirado, permanecendo as codornas em temperatura ambiente natural. Embora não tivesse sob efeito de aquecimento, as temperaturas máximas verificadas na sala experimental, a partir da quarta semana de idade, permaneceram elevadas (média semanal de $29 \mathrm{C}^{\circ}$ ), em relação à temperatura da zona de conforto das codornas $\left(21\right.$ a $\left.25 \mathrm{C}^{\circ}\right)$.

$\mathrm{Na}$ Tabela 3, estão apresentados os valores médios obtidos para o peso final, ganho de peso, consumo alimentar, conversão alimentar e empenamento, para codornas japonesas alimentadas com rações de diferentes níveis de metionina mais cistina digestível, no período de 7 aos 42 dias de idade.

Tabela 2 - Temperatura e umidade relativa do ar no interior da sala experimental Table 2 - Temperature and relative humidity of air inside of the experimental room

\begin{tabular}{lccc}
\hline $\begin{array}{l}\text { Idade das aves (dias) } \\
\text { Bird age (days) }\end{array}$ & \multicolumn{2}{c}{$\begin{array}{c}\text { Temperatura do ar }\left(\mathrm{C}^{\circ}\right) \\
\text { Air temperature }\end{array}$} & $\begin{array}{c}\text { Umidade relativa (\%) } \\
\text { Relative humidity }\end{array}$ \\
\cline { 2 - 4 } & $\begin{array}{c}\text { Máxima média } \\
\text { Maximum average }\end{array}$ & $\begin{array}{c}\text { Mínima média } \\
\text { Minimum average }\end{array}$ \\
\hline $7-13$ & $30,5 \pm 0,75$ & $29,7 \pm 0,75$ & $69,5 \pm 0,5$ \\
$14-21$ & $29,5 \pm 0,75$ & $29,0 \pm 0,75$ & $69,0 \pm 4,0$ \\
$22-28$ & $28,0 \pm 1,00$ & $27,0 \pm 1,00$ & $67,0 \pm 4,0$ \\
$29-35$ & $29,5 \pm 1,00$ & $29,0 \pm 2,00$ & $65,0 \pm 6,0$ \\
$36-42$ & $29,25 \pm 1,75$ & $28,75 \pm 2,25$ & $67,0 \pm 6,0$ \\
\hline
\end{tabular}

Tabela 3 - Efeito dos níveis de metionina mais cistina digestível sobre o peso final (g), ganho de peso (g), consumo alimentar (g), conversão alimentar $(\mathrm{g} / \mathrm{g})$ e empenamento das codornas (\%)

Table 3 - Effect of digestible methionine plus cystine levels on final weight $(g)$, weight gain $(g)$, feed intake (g), feed:gain ratio (g/g) and feather rate of quails (\%)

\begin{tabular}{|c|c|c|c|c|c|c|}
\hline \multicolumn{2}{|c|}{$\begin{array}{l}\text { Variáveis } \\
\text { Variables }\end{array}$} & \multirow[t]{2}{*}{$\begin{array}{c}\text { Peso final } \\
\text { Final weight }\end{array}$} & \multirow[t]{2}{*}{$\begin{array}{c}\text { Ganho de peso } \\
\text { Weight gain }\end{array}$} & \multirow[t]{2}{*}{$\begin{array}{l}\text { Consumo } \\
\text { Feed intake }\end{array}$} & \multirow[t]{2}{*}{$\begin{array}{l}\text { Conversão alimentar } \\
\text { Feed: gain ratio }\end{array}$} & \multirow[t]{2}{*}{$\begin{array}{c}\text { Empenamento } \\
\text { Feather rate }\end{array}$} \\
\hline $\begin{array}{l}\text { Relações } \\
\text { Relations } \\
\end{array}$ & $\begin{array}{c}\text { Met }+ \text { Cis }(\%) \\
M e t+C y s\end{array}$ & & & & & \\
\hline 0,48 & 0,555 & 124,54 & 103,01 & 446,78 & 4,34 & 3,75 \\
\hline 0,53 & 0,610 & 127,65 & 106,14 & 450,76 & 4,25 & 3,82 \\
\hline 0,58 & 0,667 & 127,73 & 106,24 & 444,32 & 4,18 & 3,98 \\
\hline 0,63 & 0,725 & 126,75 & 105,25 & 441,55 & 4,20 & 3,89 \\
\hline 0,68 & 0,782 & 128,76 & 107,23 & 443,33 & 4,14 & 4,06 \\
\hline 0,75 & 0,863 & 129,31 & 107,80 & 453,98 & 4,21 & 3,57 \\
\hline \multicolumn{2}{|c|}{$\begin{array}{l}\text { Coeficiente de variação } \\
\text { Coefficient of variation }\end{array}$} & 1,34 & 1,61 & 1,68 & 2,16 & 4,24 \\
\hline \multicolumn{2}{|c|}{ Significância } & $\mathrm{P}<0,001^{*}$ & $\mathrm{P}<0,001^{*}$ & $\mathrm{P}<0,05^{* *}$ & $\mathrm{P}<0,05^{* *}$ & $\mathrm{P}<0,001 * *$ \\
\hline
\end{tabular}

\footnotetext{
1 Relações metionina mais cistina digestível: lisina digestível (Digestible methionine plus cystine: digestible lysine ratios); * Efeito linear pelo teste $F$ (Linear effect by $F$ test).

** Efeito Quadrático pelo teste F (Quadratic effect by $F$ test).
} 
Verificou-se efeito linear $(\mathrm{P}<0,001)$, dos níveis de metionina mais cistina digestível sobre o peso final $(\mathrm{g})$ e o ganho de peso $(\mathrm{g})$ das codornas, sendo expressos respectivamente pelas equações $\mathrm{Y}=118,868+$ $12,2628 X\left(R^{2}=0,68\right)$ e $\mathrm{Y}=97,3182+12,3184 X\left(R^{2}\right.$ $=0,68)$, Tabela 3 .

Houve aumento no peso final e no ganho de peso das codornas em função dos níveis de aminoácidos sulfurosos nas rações. Estes resultados foram similares aos obtidos por Wheeler \& Latshaw (1981) e Barbosa (1998), que, trabalhando com frangos de corte em fase de crescimento, também verificaram efeito linear crescente dos níveis de aminoácidos sulfurosos sobre o ganho de peso das aves.

Embora o ganho de peso das aves tenha aumentado de forma linear, constatou-se que os dois maiores níveis de aminoácidos sulfurados, em valores absolutos de ganho de peso, praticamente não variaram, caracterizando a ocorrência de um platô a partir do nível de $0,782 \%$ de metionina mais cistina. Com este resultado ficou evidenciado que a relação metionina mais cistina digestível: lisina digestível menor que 0,68 pode comprometer a resposta de ganho de peso das codornas em fase de crescimento.

O nível de metionina mais cistina influenciou $(\mathrm{P}<0,05)$ o consumo de ração, que variou de forma quadrática, tendo diminuído até o nível estimado de $0,696 \%$, conforme a equação $Y=605,295-465,0,87 X$ $+333,640 X^{2}\left(R^{2}=0,60\right)$, Tabela 3 e Figura 1. Variação

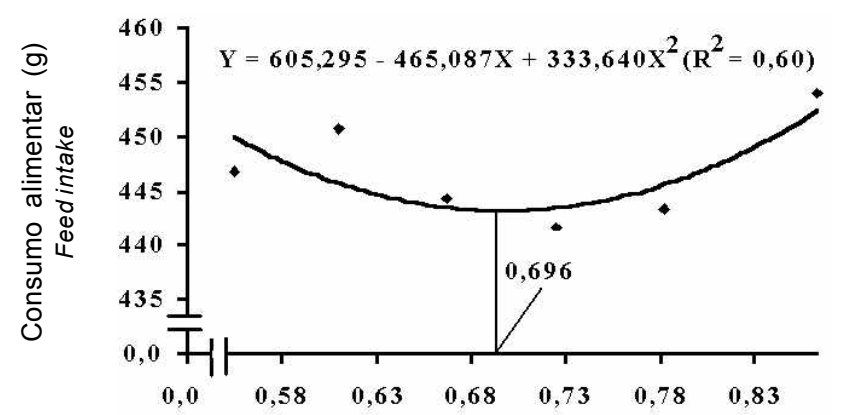

Níveis de metionina mais cistina digestível (\%) Methionine plus digestible cystine levels

Figura 1 - Efeito dos níveis de metionina mais cistina digestível sobre o consumo alimentar de codornas japonesas em crescimento.

Figure 1 - Effect of digestible methionine plus cystine levels on feed intake of growing Japanese quails. similar do consumo de ração em razão da alteração do nível de metionina mais cistina da ração foi observado por Barbosa (1998), em estudos conduzidos com frangos de corte. Com a resposta de consumo de ração ocorrida neste estudo ficou caracterizado que; tanto a diferença de aminoácidos sulfurados, caracterizado por relação metionina mais cistina digestível: lisina digestível na proteína, menor que 0,58 , quanto o excesso, caracterizado por uma relação entre esses mesmos aminoácidos acima de 0,68, resultam em similar resposta no aumento do consumo de ração pelas codornas.

A eficiência com que as codornas utilizaram o alimento também foi influenciado $(\mathrm{P}<0,05)$ pelo nível de aminoácidos sulfurados da ração, com a conversão alimentar das aves melhorando até o nível de $0,758 \%$ de metionina mais cistina, estimado pela equação $\mathrm{Y}=6,61566-6,48492 \mathrm{X}+4,279828 \mathrm{X}^{2}$ $\left(\mathrm{R}^{2}=0,92\right)$, Figura 2 .

No nível que se observou a melhor resposta de conversão alimentar a relação metionina mais cistina digestível: lisina digestível na proteína correspondeu a 0,66 .

Com estes resultados pode-se inferir que a exigência de metionina mais cistina, para melhor resposta de ganho de peso, situa-se acima daquela para conversão alimentar, e que os níveis de metionina mais cistina total preconizados para codornas em crescimento pelo NRC (1994) e por Svacha et al.

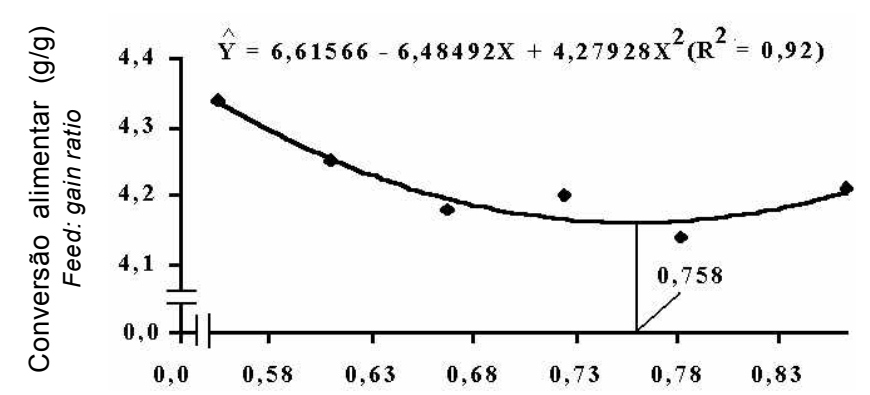

Níveis de metionina mais cistina digestível (\%) Methionine plus digestible cystine levels

Figura 2 - Efeito dos níveis de metionina mais cistina digestível sobre a conversão alimentar de codornas japonesas em crescimento.

Figure 2 - Effect of digestible methionine plus cystine levels on feed: gain intake of growing Japanese quails.

R. Bras. Zootec., v.32, n.5, p.1174-1181, 2003 
(1970), por corresponderem a uma relação de 0,58 e 0,54 com a lisina total, respectivamente, não atendem a exigência dessas aves para máximo desempenho.

Foi observado efeito quadrático $(\mathrm{P}<0,01)$ dos níveis de metionina mais cistina digestível sobre o empenamento das aves, que aumentou até o nível de $0,699 \%$, estimado pela equação $\mathrm{Y}=-2,72085+$ $19,2079 X-13,7387 X^{2}\left(R^{2}=0,72\right)$, Figura 3.

Este resultado foi semelhante aos obtidos por Pest et al. (1996) e Colnago (1996), que também

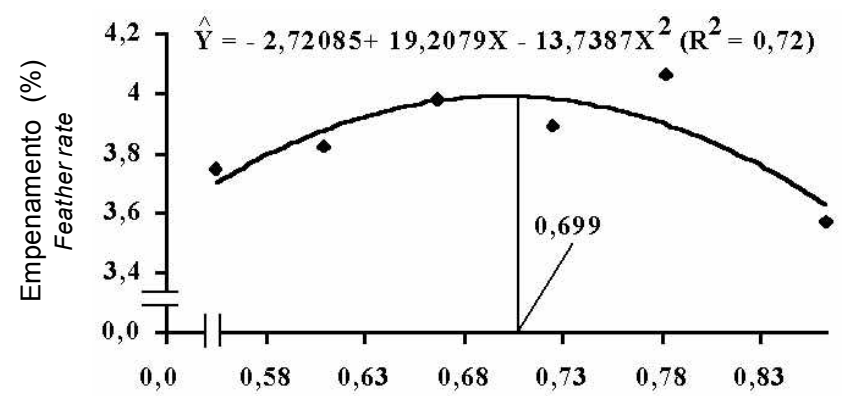

Níveis de metionina mais cistina digestível (\%) Methionine plus digestible cystine levels

Figura 3 - Efeito dos níveis de metionina mais cistina digestível sobre o empenamento das codornas japonesas.

Figure 3 - Effect of digestible methionine plus cystine levels on feather rate of Japanese quails. verificaram efeito positivo do nível de aminoácidos sulfurados com o empenamento das aves. Esta relação positiva entre o empenamento das aves e a concentração de aminoácidos sulfurados na ração pode ser explicado pela alta concentração relativa dos aminoácidos sulfurados nas penas. Considerando que o nível de aminoácidos sulfurados que proporcionou o maior empenamento das aves ficou sensivelmente abaixo das que promoveram melhores respostas de ganho de peso e conversão alimentar, pode-se afirmar que este parâmetro não é adequado para estabelecer a exigência de metionina mais cistina para codornas em crescimento.

Os resultados de composição química e deposição de proteína corporal das codornas japonesas abatidas

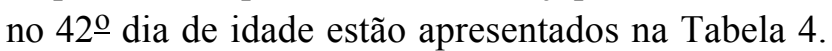

Verificou-se efeito $(\mathrm{P}<0,05)$ dos níveis de metionina mais cistina digestível sobre os parâmetros de composição química corporal avaliados, que variaram de forma quadrática, conforme as equações apresentadas na Tabela 5 .

A redução observada na porcentagem de água corporal das codornas com o aumento no nível de metionina mais cistina até o nível estimado de $0,70 \%$, contrasta com o resultado obtido por Barbosa (1998), que trabalhando com frangos de corte, constatou aumento no teor de umidade da carcaça em razão da elevação na concentração de aminoácidos sulfurados da ração. Já a resposta obtida para a porcentagem de

Tabela 4 - Efeito dos níveis de metionina mais cistina digestível sobre a composição química e deposição de proteína corporal de codornas japonesas

Table 4 - Effect of digestible methionine plus cystine levels on bodily chemical composition and deposition of bodily protein of Japanese quails

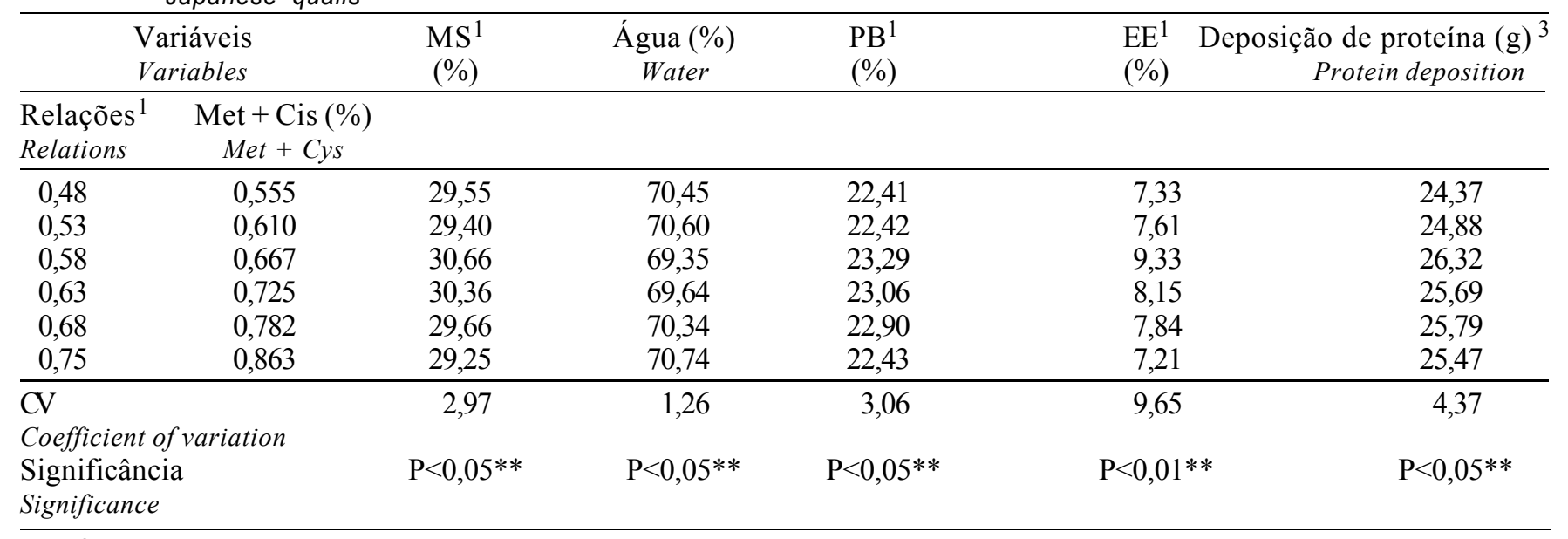

\footnotetext{
** Efeito quadrático pelo teste $\mathrm{F}$ (Quadratic effect by $F$ test).

${ }_{1}^{1} \mathrm{MS}$ - matéria seca (dry matter), PB - proteína bruta (crude protein), EE - extrato etéreo (ether extract).

${ }^{2}$ Relações metionina mais cistina digestível (\%):lisina digestível (\%) (Digestible methionine plus cystine [\%]:digestible lysine[\%] ratios).

3 Deposição de proteína corporal - 7 a 42 dias de idade (Deposition of body protein - from 7 to 42 days of age).
} 
Tabela 5 - Equações de regressão e seus respectivos níveis máximo e mínimo de metionina mais cistina verificados para as variáveis de composição química e deposição de proteína e gordura corporal das codornas

Table 5 - Regression equations and your respective levels maximum and minimum of methionine plus cystine observed for chemical composition and body fat and protein deposition of quails

\begin{tabular}{|c|c|c|c|c|}
\hline \multirow[t]{2}{*}{$\begin{array}{l}\text { Variável } \\
\text { Variable }\end{array}$} & \multirow[t]{2}{*}{$\begin{array}{l}\text { Equação } \\
\text { Equation }\end{array}$} & \multirow[t]{2}{*}{$\mathrm{R}^{2}$} & \multicolumn{2}{|c|}{$\begin{array}{c}\text { Níveis de Met }+ \text { Cis }(\%) \\
\text { Met }+ \text { Cys levels }\end{array}$} \\
\hline & & & $\begin{array}{l}\text { Máximo } \\
\text { Maximum }\end{array}$ & $\begin{array}{l}\text { Mínimo } \\
\text { Minimum }\end{array}$ \\
\hline$\overline{\mathrm{MS}}$ & $Y=10,1921+57,3117 X-40,9335 X^{2}$ & 0,61 & 0,700 & - \\
\hline Água (Water) & $Y=89,8079-57,3117 X+40,9335 X^{2}$ & 0,61 & & 0,700 \\
\hline PB & $Y=7,28209+44,1448 X-30,8218 X^{2}$ & 0,74 & 0,716 & - \\
\hline $\mathrm{EE}$ & $\mathrm{Y}=-23,8212+92,384 \mathrm{X}-65,6109 \mathrm{X}^{2}$ & 0,70 & 0,704 & - \\
\hline Deposição de proteína & $Y=0,847272+67,4609 X-45,2397 X^{2}$ & 0,77 & 0,746 & - \\
\hline
\end{tabular}

${ }^{1}$ MS - matéria seca (dry matter); PB - proteína bruta (crude protein); EE - extrato etéreo (ether extract); deposição de proteína corporal (body protein deposition).

proteína corporal esta consistente com os dados obtidos por Edwards Jr. (1981) para composição das carcaças das codornas japonesas em diferentes idades.

As variações observadas na composição química corporal das codornas contribuíram para que também ocorresse variação $(\mathrm{P}<0,05)$ na taxa de deposição de proteína corporal entre os diferentes níveis de metionina mais cistina envolvidos com a máxima taxa de deposição de proteína, ocorrendo no nível estimado de $0,746 \%$ (Tabela 5; Figura 4).

Os resultados de aumento na taxa de deposição de proteína corporal associado com a diminuição no teor de umidade verificados neste estudo são consistentes

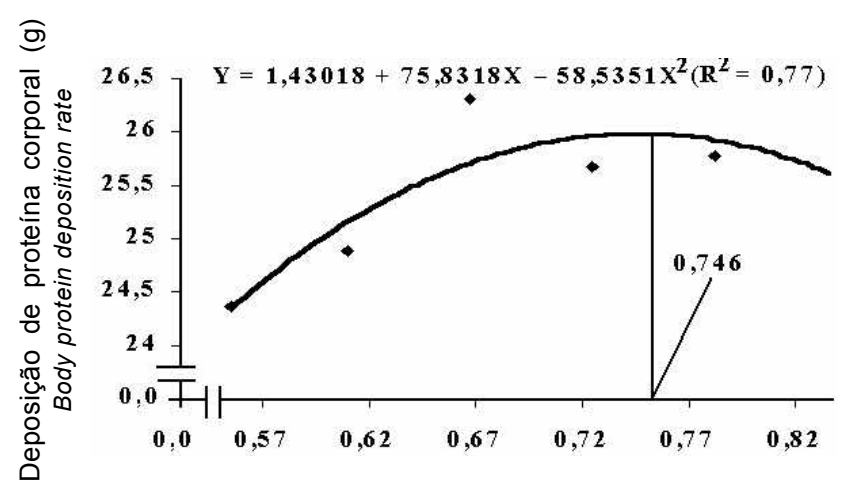

Níveis de metionina mais cistina digestível (\%) Methionine plus digestible cystine levels

Figura 4 - Efeito dos níveis de metionina mais cistina digestível, sobre a deposição de proteína corporal das codornas japonesas.

Figure 4 - Effect of digestible methionine plus cystine levels on body protein deposition of Japanese quails. com os observados por Kirkipinar \& Oguz (1995), em estudos conduzidos com codornas japonesas machos, recebendo diferentes níveis de proteína na ração.

Considerando que o ganho em proteína corporal, por agregar maior quantidade de água, é mais eficiente que o de gordura, o aumento na taxa de deposição de proteína justificaria a melhoria ocorrida na conversão alimentar das codornas.

\section{Conclusões}

A exigência em metionina mais cistina digestível para codornas japonesas em crescimento (dos 7 aos 42 dias de idade) foi estimada em $0,758 \%$ da ração, para consumo diário de $91,43 \mathrm{mg}$ de metionina mais cistina digestível, correspondendo à relação metionina mais cistina digestível: lisina digestível de 0,66.

\section{Literatura Citada}

BARBOSA, R.J Exigência de metionina + cistina para frangos de corte na fase de crescimento e acabamento. Viçosa, MG: Universidade Federal de Viçosa, 1998. 84p. Dissertação (Mestrado em Zootecnia) - Universidade Federal de Viçosa, 1998.

COLNAGO, G.L. Fatores que influenciam as exigências nutricionais de aves. In: SIMPÓSIO INTERNACIONAL SOBRE EXIGÊNCIAS NUTRICIONAIS DE AVES E SUÍNOS, 1996, Viçosa, MG. Anais...Viçosa, MG: Universidade Federal de Viçosa, 1996. p.345-360.

CONHOLATO, G.S. Exigência de lisina digestível para frangos de corte machos. Viçosa, MG: Universidade Federal de Viçosa, 1998. 79p. Dissertação (Mestrado em Zootecnia) Universidade Federal de Viçosa, 1998.

EDWARDS JR., H. M. Carcass composition studies. 3. Influences of age, sex and calorie-protein content of the diet on carcass composition of Japanese quail. Poultry Science, v.60, n.11, p.2506-2512, 1981. 
KIRKIPINAR, F.; OGUZ, I. Influence, of various dietary protein levels on carcass composition in the male Japanese quail (Coturnix coturnix japonica). British Poultry Science, v.36, n.4, p.605-610, 1995.

NATIONAL RESEARCH COUNCIL - NRC. Nutrient requirements of poultry. Washington, D.C.: National Academic Press, 1994. p.44-45.

PEST, G.M.; LECLERCQ, B.; CHAGNEAU, A.M. et al. Effect of the naked neck $(\mathrm{Na})$ gene on the sulfur-containing amino acid requirements of broilers. Poultry Science, v.75, n.3, p.375-380, 1996.

REIS, L.F.S.D. Codornizes, criação e exploração. Lisboa, Agros, 10, 1980. 222p.

ROSTAGNO, H.S.; BARBARINO JR., P.; BARBOSA, W.A. Exigências nutricionais das aves determinadas no Brasil. In: SIMPÓSIO INTERNACIONAL SOBRE EXIGÊNCIAS NUTRICIONAIS DE AVES E SUÍNOS, Viçosa, MG, 1996. Anais...Viçosa, MG: Universidade Federal de Viçosa, 1996, p.361-388

ROSTAGNO, H.S.; ALBINO, L.F.T.; DONZELE, J.L. et al. Composição de alimentos e exigências nutricionais. (Tabelas Brasileiras). Viçosa, MG: Universidade Federal de Viçosa, 2000. 141p.
SILVA, D.J. Análise de alimentos (Métodos químicos e biológicos). Viçosa, MG: Universidade Federal de Viçosa, 1990. $160 \mathrm{p}$

SINGH, R.V.; NARAYAN, R. Produção de codornas nos trópicos. In: SIMPÓSIO INTERNACIONAL DE COTURNICULTURA, 1., Lavras, 2002. Anais...Lavras: Universidade Federal de Lavras, 2002. p.27-36.

SVACHA, A.; WEBER, C.W.; REID, B.L. Lysine, methionine and glycine requirements of Japanese quail to five weeks of age. Poultry Science, v.49, n.1, p.54-59, 1970.

UNIVERSIDADE FEDERAL DE VIÇOSA - UFV. SAEG Sistema para análise estatística e genética. Versão 8.0. Viçosa, MG: Fundação Arthur Bernardes, 1999.

WHEELER, K.B.; LATSHAW, J.D. Sulfur amino acid requirements and interactions in broilers during two growth periods. Poultry Science, v.60, n.2, p.228-236, 1981.

Recebido em: $14 / 08 / 02$

Aceito em: 13/11/02 